\title{
Sindicalismo, Processo Decisório e Reforma da Previdência no Governo Lula*
}

\author{
Sidney Jard da Silva ${ }^{1}$ \\ ${ }^{1}$ Professor do Centro de Engenharia, Modelagem e Ciências Sociais Aplicadas da Universidade Federal do \\ ABC (CECS/UFABC). Santo André, SP. Brasil. \\ E-mail: sidney.jard@ufabc.edu.br
}

\section{INTRODUÇÃO}

Better understanding the role of Congress is a new field of study that diverges from the executive dominance paradigm.

(Vicente Palermo)

\begin{abstract}
To início dos anos 2000, o cientista político argentino Vicente 1 Palermo publicou, nesta Dados - Revista de Ciências Sociais, o artigo intitulado "Como se governa o Brasil? O debate sobre instituições políticas e gestão de governo" (Palermo, 2000). Anos mais tarde, conforme observa o próprio autor (Palermo, 2016), o referido artigo continua provocando reações da comunidade acadêmica brasileira e internacional.
\end{abstract}

Inspirado nos dois textos acima citados, o presente artigo retoma o debate sobre os processos de governo e sobre as tomadas de decisões no sistema político brasileiro. A principal contribuição deste estudo é apresentar bases empíricas que confirmam a importância de se com-

\footnotetext{
${ }^{*}$ Uma versão preliminar do presente artigo foi publicada como working paper na Oficina do CES, $\mathrm{n}^{\circ}$ 445, durante meu estágio de pós-doutoramento no Centro de Estudos Sociais/Universidade de Coimbra (CES/UC), sob a supervisão do professor doutor Elísio Estanque. Também tive a oportunidade de debater a referida versão no 42 Encontro Anual da Associação Nacional de Pós-Graduação e Pesquisa em Ciências Sociais (Anpocs), GT 33 - Trabalho, Trabalhadores e Ação Coletiva, coordenado pelos colegas Marco Aurélio Santana e Roberto Véras de Oliveira. Sou grato aos editores e pareceristas da DADOS pelas valiosas críticas e sugestões para o aprimoramento da versão final deste artigo. Por fim, agradeço aos integrantes do grupo de pesquisa Política, Políticas Públicas e Ação Coletiva (3 PAC) pelo estímulo intelectual para a publicação deste trabalho.
}

DADOS, Rio de Janeiro, vol.64 (2): e201800215, 2021

https://doi.org/10.1590/dados.2021.64.2.232 
binar a análise da morfologia institucional com outras variáveis, notadamente a capacidade de negociação e de cooperação entre os atores políticos, para se explicar a produção de políticas públicas.

Nessa perspectiva analítica, mais do que impor a sua agenda, o presidente da República deve negociar com o Congresso Nacional as suas posições e proposições. O Poder Legislativo não está excluído nem é subserviente ao Poder Executivo, muito pelo contrário, o protagonismo da Presidência da República no processo decisório das políticas públicas se dá por intermédio de um intenso e tenso processo de negociação (Armijo, Faucher e Dembinska, 2006; Coutinho, 1998; Gontijo, 2012; Palermo, 2016, 2000; Silveira e Silva, 2014). Em última instância, é a capacidade de negociação entre Executivo e Legislativo a principal variável explicativa para a alta ou para a baixa probabilidade de mudança das políticas públicas.

Assim sendo, por meio da análise da participação da bancada sindical no processo decisório da reforma da Previdência, este artigo busca demonstrar a importância dos acordos políticos na relação entre Executivo e Legislativo no Brasil. Tal como observa Palermo (2000), se por um lado as questões relativas ao funcionamento institucional de um sistema político podem ser abordadas a partir da identificação conceitual dos atores com poder de veto e das regras institucionais, por outro, a forma como os governos efetivamente tomam as decisões deve ser analisada em bases empíricas.

É justamente essa base empírica que busco apresentar nas próximas seções deste artigo, no sentido de demonstrar a importância da cooperação e da negociação no processo de produção das políticas públicas. Para tanto, como dito acima, tomo como foco de análise a participação dos deputados e senadores sindicalistas no trâmite legislativo da reforma da Previdência do governo de Luiz Inácio Lula da Silva.

Além desta breve introdução, o trabalho está divido em mais seis seções. Na primeira, apresento um balanço das principais contribuições teóricas para o estudo do processo decisório da reforma da Previdência no Brasil. Na segunda, descrevo a natureza inédita da "reforma da reforma" do governo Lula. Na terceira, apresento uma radiografia do bloco sindicalista no Congresso Nacional. Na quarta, analiso o trâmite legislativo da PEC 77/2003. Na quinta, discuto as vicissitudes do acordo político que deu origem à chamada PEC Paralela. Nas con- 
siderações finais, retomo os principais achados da pesquisa, os quais questionam a visão corrente na litetura acadêmica no que tange à predominância do Executivo sobre o Legislativo no processo decisório das reformas previdenciárias.

\section{REFORMA DA PREVIDÊNCIA E PROCESSO DECISÓRIO}

A análise de processo decisório dedica particular atenção para a natureza da política pública e para o arranjo do jogo político-institucional. Medidas de alta visibilidade que impõem perdas imediatas e concentradas a grupos de interesse específicos e benefícios incertos e difusos para o conjunto dos cidadãos são consideradas "politicamente inviáveis" (Arnold, 1998, 1990; Figueiredo e Limongi, 2001; Melo, 2002, 2004; Pierson, 1997).

Não obstante, entre a última década do século XX e o primeiro decênio do século XXI, em diversas partes do mundo, governos de diferentes orientações político-ideológicas conduziram reformas previdenciárias que impuseram importantes derrotas a poderosos grupos de interesse. Como explicar esse resultado político? Como explicar o sucesso desses governos em suas políticas de imposição de perdas? Como explicar essa aparente disjunção entre teoria e prática?

Há pelo menos duas formas de abordar as questões colocadas acima: a primeira, é concentrar o foco da análise na capacidade de os governos manejarem as regras do processo decisório no sentido de diminuir a visibilidade das perdas impostas aos grupos de interesse; a segunda, é direcionar o foco para a capacidade de os grupos de interesse explorarem as características político-institucionais do processo decisório para aumentar a visibilidade das perdas impostas. Prevalecendo a primeira, a probabilidade das reformas aumenta; prevalecendo a segunda, a probabilidade das reformas diminui. Entre um extremo e o outro, localizam-se as "reformas possíveis".

Sem desconsiderar a importância do primeiro olhar, que poderia ser classificado como top down (do planalto para a planície) este trabalho se alinha mais à segunda perspectiva analítica, que poderia ser chamada de bottom up (da planície para o planalto) ${ }^{1}$. Em outras palavras, concentra-se mais nas estratégias de reação dos grupos de interesse às políticas reformistas do que nas estratégias de ação dos governos 
para aprovar as reformas. Destaca ainda que ambas são mediadas pelas regras do jogo político-institucional, as quais, a depender dos seus desenhos específicos, podem favorecer a ação dos governos reformistas ou a reação dos grupos de interesse (Immergut, 1996; Tsebelis, 1998, 1997).

No Brasil, os estudos do processo decisório das reformas previdenciárias foram profundamente marcados pela primeira perspectiva teórica. Desde o trabalho seminal de Figueiredo e Limongi (1998), passando por Coelho (2001, 1999), Melo (2002), Melo e Anastasia (2006), Nakahodo e Savoia (2008), Hiroi (2008) e Gontijo (2012), todos esses estudiosos se concentraram em explicar como as características político-institucionais do sistema político brasileiro condicionaram a capacidade de o Executivo submeter e aprovar mudanças no sistema previdenciário.

Os estudos de Vera Coelho $(2001,1999)$ são os mais representativos dessa tendência em concentrar nas características político-institucionais do Poder Executivo as variáveis explicativas para os resultados alcançados pelas reformas previdenciárias. Em análise comparativa das reformas argentina, brasileira e uruguaia, a autora destaca as disputas entre burocracias, especialistas e políticos na formulação de projetos para a reforma da Previdência no interior do Executivo. Em sua conclusão, Coelho (2001:108) é categórica em afirmar que "viabilizar um processo de mudança das políticas públicas significa alterar não só a balança de poder entre os atores sociais, mas também entre os atores estatais".

Em uma análise comparativa das administrações de Fernando Henrique Cardoso e de Luiz Inácio Lula da Silva, Nakahodo e Savoia (2008) também consideram o Governo Federal como o ator mais importante nos processos de reforma da Previdência social. No entanto, ressalvam que o Congresso é "o principal palco para o aprimoramento do sistema previdenciário" (2008:56). Assim sendo, a habilidade de negociar, levando em consideração os limites impostos pelas regras do cenário político-institucional é de fundamental importância para o sucesso (ou fracasso) das reformas.

Figueiredo e Limongi (1998), por sua vez, foram pioneiros na análise do jogo político entre Executivo e Legislativo no processo decisório da reforma da Previdência. Em um estudo crítico da suposta ingovernabilidade do país no período pós-redemocratização, os autores são 
incisivos em afirmar que não obstante as características peculiares do sistema político brasileiro - federalismo, multipartidarismo, bicameralismo - o resultado da reforma previdenciária pode ser explicado levando-se em conta apenas a disputa entre Executivo e Legislativo no interior do Congresso Nacional.

Na mesma linha de argumentação, Gontijo (2012) destaca a importância das prerrogativas constitucionais que asseguram poderes legislativos ao presidente da República. Segundo o autor, as regras institucionais garantem ao Poder Executivo os instrumentos e recursos necessários para a mudança das políticas públicas, mesmo em um cenário político caracterizado pela multiplicidade de pontos de veto nos processos decisórios.

Melo (2002), por sua vez, chama a atenção para os elevados custos políticos das reformas previdenciárias. Nessa perspectiva teórica, o comportamento parlamentar pode ser explicado, em larga medida, pelos custos e benefícios de seguir a orientação do governo no processo de aprovação de políticas de imposição de perdas concentradas a grupos de interesse com grande capacidade de mobilização política e social.

A resistência em assumir os custos políticos da reforma da Previdência também é destacada por Hiroi (2008). Em um trabalho comparativo sobre a reforma da Previdência nos governos FHC e Lula, a autora destaca que, muito embora contasse com apoio no Senado Federal, Fernando Henrique enfrentou grande resistência ao seu projeto na Câmara dos Deputados. Lula, por sua vez, teria enfrentado resistências menores em ambas as Casas. Assim, a convergência de preferências entre a Câmara e o Senado seria a principal variável explicativa da celeridade e do alcance da reforma da Previdência no governo Lula quando comparada à reforma da Previdência no governo FHC.

Finalmente, Melo e Anastasia (2006) chamam atenção para o fato de que a reforma da Previdência constitui um jogo em múltiplas arenas, envolvendo diferentes atores e instâncias de negociação. Nesse modelo analítico, a principal variável explicativa para os distintos padrões decisórios nas reformas previdenciárias dos governos FHC e Lula são os diferentes contextos político-institucionais que envolveram a "troca de lugares" entre a situação e a oposição nas eleições legislativas e presidenciais de $2002^{2}$. 
Não obstante concentrarem a análise do processo decisório nas características peculiares do Executivo ou nas relações Executivo-Legislativo, todos os trabalhos acima citados são unânimes em reconhecer que os grupos de interesse cumprem papel importante na formação de coalizões que buscam aumentar os custos políticos das reformas previdenciárias apresentadas pelo presidente da República e negociadas no interior do Congresso Nacional.

Com efeito, a participação dos grupos de interesse no processo decisório das reformas previdenciárias é um dado relevante para se compreender a natureza subótima dessas reformas. Como será demonstrado ao longo deste artigo, invariavelmente, as negociações com amplos e diversos grupos de interesse implicam a moderação do conteúdo inicialmente ambicioso das mudanças propostas.

É justamente essa perspectiva analítica, focada na atuação parlamentar dos grupos de interesse, que este trabalho procura explorar. Governos empenhados em realizar reformas previdenciárias buscam, sobretudo, ocultar a adoção de medidas impopulares com altos custos políticos. Por sua vez, grupos de interesse empenhados em manter o status quo buscam aumentar a visibilidade das medidas impopulares e os custos políticos da mudança da política pública.

As alterações demográficas e as novas configurações do mercado de trabalho são variáveis que pressionam governos de diferentes orientações político-ideológicas a promoverem reformas nos sistemas previdenciários (Jard da Silva e Ferraz, 2019; Gontijo, 2012; Marques, Batich e Mendes, 2003; Ortiz et al. 2019): de um lado, o declínio da taxa de natalidade e o aumento da expectativa de vida contribuem para tornar mais estreitas a relação entre trabalhadores ativos e inativos, o que afeta negativamente as contas da Previdência Social; de outro, a reestruturação produtiva, a flexibilização das relações trabalhistas, o desemprego, o subemprego e o trabalho precário aprofundam as dificuldades de financiamento dos sistemas públicos de repartição ${ }^{3}$.

Contudo, assim como em uma situação demográfica e trabalhista favorável, a expansão dos regimes previdenciários começou a partir dos grupos mais organizados para os menos organizados (Lewis e Lloyd-Sherlock, 2002; Malloy, 1986; Mesa-Lago, 1977). E em momentos de pressão demográfica negativa e crise do mercado do trabalho, a resistência à retração da Previdência Social também começa dos grupos 
mais organizados para os menos organizados. Em outras palavras, partem daquelas categorias profissionais que contam com uma melhor posição em termos de cobertura e valor dos benefícios para aquelas que contam com uma posição mais modesta no interior do sistema previdenciário.

Não por acaso, os servidores públicos e suas entidades representativas figuraram como a vanguarda da luta contra a reforma da Previdência não apenas no Brasil, mas em todo o mundo. No caso brasileiro, tanto no governo FHC quanto no governo Lula, as principais greves, paralisações e mobilizações durante o debate da reforma da Previdência foram realizadas pelo funcionalismo público. No entanto, há relativo consenso na literatura acadêmica no sentido de apontar que a resistência do movimento sindical à agenda reformista do governo Lula não foi tão forte quanto o embate contra a agenda reformista do governo FHC (Gontijo, 2012; Nakahodo e Savoia, 2008).

A desigualdade entre as diferentes categorias de filiados ao sistema previdenciário - fundamentalmente a dualidade entre o regime de previdência dos trabalhadores da iniciativa privada e os diversos regimes previdenciários dos servidores públicos (municipais, estaduais e federal) - alimenta uma segunda disputa importante em torno da visibilidade do processo decisório das reformas previdenciárias. Mas, ao contrário da disputa exposta acima, dessa vez são os governos reformistas que buscam contrapor os "privilégios" de categorias profissionais específicas aos benefícios "modestos" recebidos pela massa dos trabalhadores, a qual, em sua grande maioria conta apenas com acesso aos direitos básicos da Previdência Social.

No processo decisório da reforma previdenciária, essa nova disputa se materializa na ação dos governos que procuram dividir a resistência à mudança explorando as diferenças entre as classes profissionais $\mathrm{e}$ aumentando a visibilidade dos chamados "privilégios", de um lado; e na reação defensiva dos grupos de interesse no sentido de afirmar a "unidade" na defesa da Previdência Social, buscando minimizar as distinções no acesso e nas modalidades de benefícios recebidos por diferentes categorias de trabalhadores, de outro.

Esse foi um dos principais pontos de tensão na relação entre Lula, um ex-sindicalista fundador do Partido dos Trabalhadores (PT) e da Central Única dos Trabalhadores (CUT), e o movimento sindical 
brasileiro. A reforma do governo Lula (2003-2010) resgatava diversos pontos derrotados na proposta de reforma da Previdência do governo FHC (1995-2002), os quais tinham sido duramente rechaçados pelos sindicatos cutistas. No entanto, Lula explorou as diferenças entre os trabalhadores do setor público e do privado para enfraquecer a resistência do movimento sindical ao seu projeto reformista ${ }^{4}$.

Nesse ponto, é importante observar que centenas de cargos no alto escalão do governo foram ocupados por sindicalistas, inclusive nos próprios ministérios do Trabalho e da Previdência, o que também contribuiu para arrefecer o rechaço do movimento sindical à sua proposta de reforma previdenciária. Nas palavras de Cardoso:

Pode-se gastar muita tinta nomeando as pessoas que ocuparam os vários escalões do poder de Estado, egressas da CUT e dos movimentos sociais. [...] A CUT não foi cooptada pelo governo. Ela chegou ao poder com Lula e tornou-se importante manancial de novas elites, agora de extração popular, com lastro no mundo do trabalho, aptas à gestão do Estado capitalista. $(2015: 503)$

Contudo, em regimes democráticos, o destino das reformas previdenciárias é decidido em um "aninhado" jogo político-institucional que envolve não apenas governos e grupos de interesse (Tsebelis, 1998, 1997), mas fundamentalmente a relação entre os poderes Executivo e Legislativo ${ }^{5}$. Nessa perspectiva teórica, no caso brasileiro, ganha particular importância a análise da organização do processo decisório no interior do Congresso Nacional (Gomes, 2006; Lemos, 2006; Ricci, 2003; Santos e Almeida, 2011).

Como bem observou Melo (2002), os custos políticos das reformas previdenciárias não são concentrados apenas no Poder Executivo, principal autor do projeto de reforma constitucional enviado para apreciação do Legislativo; mas também nos deputados e senadores que são chamados a se pronunciarem em matérias impopulares e de grande interesse para os seus respectivos eleitorados.

Os legisladores, por sua vez, são sensíveis à atuação de "grupos atentos e mobilizados" que buscam aumentar a visibilidade das políticas impopulares a serem impostas a setores da sua clientela eleitoral. Assim, "assumindo que o eleitor vota retrospectivamente, isto é, punindo ou 
recompensando os atos passados de seus representantes, estes são forçados a antecipar as possíveis reações de grupos até então apáticos e não mobilizados" (Figueiredo e Limongi, 1998:66).

Este artigo busca compreender como governo e grupos de interesse são capazes de explorar, ou até mesmo suplantar, os arranjos institucionais existentes para fazer valer um processo negociado de reforma da Previdência. Como em outros trabalhos sobre o tema, o problema da pesquisa é formulado nos seguintes termos:

Em situações político-institucionais em que um governo considerado aliado envia ao Congresso Nacional projetos que contrariam interesses de importantes setores do movimento sindical, qual é a posição predominante na bancada sindicalista? Defender as demandas da sua base de representação social ou seguir a orientação do partido e/ou coalizão partidária da qual faz parte? ${ }^{6}$ (Jard da Silva, 2018:2).

\section{A PEC SINDICAL DA PREVIDÊNCIA}

O objetivo deste artigo é analisar a participação dos parlamentares sindicalistas (deputados e senadores) no processo decisório da Proposta de Emenda à Constituição no 77, de 2003 (PEC 77/2003). A chamada PEC Paralela da Previdência foi elaborada por iniciativa do senador Paulo Paim (PT/RS), um dos mais destacados parlamentares da bancada sindical no legislativo brasileiro. ${ }^{7}$

A análise do trâmite legislativo da PEC 77/2003 corrobora a tese da importância das negociações parlamentares nos processos decisórios das políticas públicas. Conforme pretendo demonstrar ao longo deste artigo, a reforma da Previdência do governo Lula só foi possível devido a um acordo político envolvendo alguns dos principais atores do Executivo e do Legislativo brasileiros, entre eles o próprio presidente da República, o presidente da Câmara dos Deputados e o presidente do Senado Federal.

O propósito da PEC 77/2003 era alterar vários pontos da PEC 67 /2003, ainda então em tramitação no Senado Federal, sem provocar mudanças no texto desta última, evitando assim o seu retorno à Câmara dos Deputados. Entre os principais pontos da nova proposta de emenda constitucional, destacavam-se: i) a garantia da integralidade dos bene- 
fícios para os funcionários que ingressaram no serviço público até 31 de dezembro de 2003; ii) a paridade no reajuste dos benefícios para os funcionários que igualmente ingressaram no serviço público até 31 de dezembro de 2003; iii) a extensão da paridade para as pensões; e, iv) a aplicação da regra de transição $(95 / 85)$ para os funcionários que ingressaram até 16 de dezembro de 1998.

\section{Quadro 1}

PEC Paralela da Reforma da Previdência PEC 77/2003

\begin{tabular}{|c|c|}
\hline Item & Descrição \\
\hline Integralidade & $\begin{array}{l}\text { Garante aposentadoria integral e paridade plena ao servidor que, tendo } \\
\text { ingressado no serviço público até } 31 / 12 / 2003 \text {, preencher os requisitos do } \\
\text { Art. } 6 \text { - da Emenda Constitucional } 41 \text { ( } 35 \text { ou } 30 \text { anos de contribuição, se } \\
\text { homem ou mulher, } 60 \text { ou } 55 \text { de idade, } 20 \text { anos de serviço público, sendo } \\
10 \text { na carreira e } 5 \text { no cargo). }\end{array}$ \\
\hline Paridade plena & $\begin{array}{l}\text { Assegura paridade plena a todos os servidores que, tendo ingressado no } \\
\text { serviço público até } 31 / 12 / 2003 \text {, preencherem todas as exigências para } \\
\text { aposentadoria integral (Art. } 6^{0} \text { e } 7^{0} \text { da Emenda Constitucional 41, de 2003). }\end{array}$ \\
\hline $\begin{array}{l}\text { Paridade das } \\
\text { pensões }\end{array}$ & $\begin{array}{l}\text { Fica assegurada a aplicação da regra de paridade plena, constante do art. } \\
7^{\circ} \text { da Emenda Constitucional 41, de 2003, às revisõos de pensões deriva- } \\
\text { das de proventos de servidores falecidos cujas aposentadorias tenham } \\
\text { sido concedidas com base na regra de transição. }\end{array}$ \\
\hline $\begin{array}{l}\text { Regra de } \\
\text { Transição Geral }\end{array}$ & $\begin{array}{l}\text { Possibilita ao servidor que ingressou no serviço público até } 16 \text { de } \\
\text { dezembro de } 1998 \text { se aposentar integralmente e com paridade plena } \\
\text { antes da idade mínima exigida na Emenda Constitucional } 41 \text {, desde que } \\
\text { tenha pelo menos } 25 \text { anos de serviço público, } 15 \text { na carreira, } 5 \text { no cargo } \\
\text { e comprove tempo de contribuição acima do exigido, no caso de } 30 \\
\text { anos para a mulher e de } 35 \text { para o homem. Para cada ano que o servidor } \\
\text { exceder no tempo de contribuição, ele poderá reduzir ou abater } 1 \text { ano na } \\
\text { idade mínima. }\end{array}$ \\
\hline
\end{tabular}

Fonte: Departamento Intersindical de Assessoria Parlamentar (Diap). Elaboração do autor.

Além dos assuntos relacionados aos benefícios previdenciários do conjunto dos servidores públicos, a PEC Paralela também abordou outros pontos como: i) o subteto salarial do funcionalismo público nos âmbitos estadual e municipal; ii) a extensão das regras de transição para a aposentaria especial dos professores da Educação Infantil e do Ensino Médio; iii) a contribuição dos inativos; iv) a contribuição das empresas para o INSS (Instituto Nacional do Seguro Social); e, v) a inclusão previdenciária das pessoas de baixa renda. Afora o último 
ponto, os demais tinham como objetivo amenizar os impactos negativos da PEC 67/2003 sobre determinados setores do funcionalismo público (i, ii e iii) ou sobre empregadores da iniciativa privada (iv).

No caso particular da definição dos subtetos dos estados, do Distrito Federal e dos municípios, vale a pena ressaltar que se tratava de modificações de interesse do médio e do alto escalão dos servidores públicos, notadamente juízes, desembargadores, promotores, defensores, procuradores e agentes tributários. Categorias profissionais situadas em órgãos estratégicos do aparelho do Estado, o que lhes garantia posições igualmente diferenciadas no sistema previdenciário brasileiro. Assim, muito embora a PEC Paralela tenha sido apresentada como uma medida necessária para corrigir injustiças cometidas contra todos os servidores públicos (ativos e inativos), a mesma proposição acabou por reafirmar a histórica assimetria na concessão de benefícios previdenciários entre os diferentes regimes próprios de previdência.

Portanto, além da pressão da base do funcionalismo público, os interesses do médio e do alto escalão dos servidores (notadamente, as categorias profissionais vinculados ao Poder Judiciário) foi de fundamental importância para a apresentação e posterior aprovação da PEC Paralela da Previdência, a qual, entre outros temas, contemplava demandas específicas dessas categorias, como era o caso da não submissão de suas carreiras aos tetos previdenciários estabelecidos para os servidores públicos dos Poderes Executivo e Legislativo.

A defesa dos interesses particulares do médio e do alto escalão do funcionalismo público, bem como dos próprios parlamentares que votariam a matéria, foi duramente criticada por integrantes da bancada sindical ao longo do debate da PEC Paralela. Como podemos destacar na intervenção, no dia 11 de dezembro de 2003, da senadora Heloísa Helena (PT/AL):

As três palavrinhas não saíram da $\operatorname{PEC~nํㅡㄴ~} 67$, porque, se isso acontecesse, muito mais coisas teriam de sair, e a proposta voltaria para a Câmara. No entanto, as três palavrinhas mágicas saíram da PEC no 77. E aquilo que estava na Constituição e que imporia teto aos penduricalhos dos parlamentares sumiu; as palavrinhas "ou de qualquer outra natureza", que estavam na PEC no 67, foram objetivamente retiradas. (Diário do Senado Federal, 2003:40733) 
Crítica similar à convergência de interesses entre os parlamentares (deputados e senadores) e o médio e o alto escalão do funcionalismo público na discussão da PEC Paralela também esteve presente no pronunciamento, no dia 9 de julho de 2004, do deputado sindicalista Eduardo Valverde (PT/RO):

Hoje, não estaremos fazendo justiça, se só aprovarmos aqui a PEC Paralela - muito justa, apesar de o Senado, no meu entender, ter tentado privilegiar alguns setores, principalmente aqueles que podem acumular vencimentos e proventos. Na verdade, essa acumulação deveria ser proibida por lei. No entanto, é permitida a alguns setores - no Senado, devido à grande quantidade de ex-governadores entre seus membros, pode ocorrer com facilidade essa cumulação - , enquanto trabalhadores que sequer têm condições de trabalhar em ambiente seguro não têm possibilidade de se aposentar ao completar 65 anos. (Diário da Câmara dos Deputados, 2004:32192)

Em síntese, a aprovação da PEC Paralela da Previdência configurou-se em um processo extremamente complexo de negociação, envolvendo os interesses de diversas categorias dos funcionalismos federal, estadual e municipal. Se por um lado a PEC 77/2003 procurava amenizar o impacto negativo da reforma sobre os servidores públicos (ativos e inativos) de menor remuneração, pensionistas de baixa renda e portadores de deficiências incapacitantes, por outro, a mesma proposta de emenda constitucional também assegurava os interesses dos setores mais bem remunerados do serviço público brasileiro, organizados sindicalmente e com forte poder de pressão sobre o Executivo, o Legislativo e o Judiciário.

\section{A BANCADA SINDICAL}

O bloco de deputados e senadores sindicalistas constitui um grupo suprapartidário bem organizado, ativo politicamente e especializado em temas relacionados aos direitos trabalhistas e sociais. Esses elementos, por si só, já justificariam uma maior atenção para a participação da bancada sindical no processo decisório da reforma da Previdência, ainda mais quando a proposta é apresentada por um governo considerado aliado pela maioria absoluta dos parlamentares sindicalistas no Congresso Nacional. 
Contudo, a importância da bancada sindical é frequentemente subestimada nas análises do processo decisório das políticas públicas, inclusive aquelas diretamente relacionadas aos interesses dos trabalhadores, como é o caso da política previdenciária. Observa-se, assim, uma enorme lacuna entre as frequentes referências à oposição das entidades sindicais em relação à reforma da Previdência e à ausência de pesquisas sobre a atuação do bloco sindicalista no trâmite legislativo da reforma previdenciária (Jard da Silva, 2018, 2016) ${ }^{8}$.

No entanto, é importante observar que em um sistema multipartidário no qual um governo de coalizão precisa reunir maioria qualificada de três quintos (308 votos) para aprovar suas propostas de reformas constitucionais, o voto disciplinado de aproximadamente $10 \%$ dos deputados e $10 \%$ dos senadores não é algo desprezível. Muito menos ainda se se tratar de uma bancada qualitativamente influente, com cargos importantes (líderes partidários, relatores de matérias, presidentes de comissões etc.) em diferentes instâncias decisórias do Poder Legislativo?

Portanto, especialmente em temas que afetam interesses dos trabalhadores organizados, como é o caso da reforma da Previdência, é de se esperar que o bloco de deputados e senadores sindicalistas tenham uma participação importante no processo decisório da política pública, tanto do ponto de vista quantitativo, por atuarem como um bloco disciplinado em torno de interesses comuns, quanto do ponto de vista qualitativo, por acumularem larga experiência de negociação e conhecimento sobre temas relativos às políticas sociais e trabalhistas.

Além disso, externamente, o aval da bancada sindicalista era de fundamental importância para dar credibilidade à nova proposta de emenda constitucional junto ao funcionalismo público ${ }^{10}$. Assim, ao longo do processo decisório da PEC Paralela, ocorreu um fato inusitado no jogo político da reforma da Previdência. Os servidores públicos que historicamente se destacaram por rejeitar sucessivas propostas de emendas constitucionais que alteravam o sistema previdenciário brasileiro, dessa vez, foram convocados a defender a "reforma da reforma":

Os servidores, na condição de principais interessados em amenizar os efeitos da reforma da Previdência, devem pressionar os deputados para que aprovem a PEC Paralela, preferencialmente de forma rápida e sem emendas. Qualquer mudança no texto resultará ou em prejuízo aos servidores, no caso de supressão, ou em atraso, no caso de mudança pontual, 
ou ainda na inviabilização do texto, na hipótese de substituição global, já que a matéria teria que retornar ao Senado. (Queiroz, 2004)

Durante o trâmite legislativo da PEC Paralela, assim como ocorrera durante o processo decisório da PEC Principal, a grande maioria dos legisladores sindicalistas se encontrava na base de sustentação do governo, notadamente no PT e no Partido Comunista do Brasil (PCdoB). Um forte indicativo político partidário de que a bancada sindical votaria, novamente, de acordo com a orientação do Executivo.

Em termos quantitativos, entre a aprovação da PEC 40/2003 e a tramitação da PEC 227/2004 ${ }^{11}$, a única mudança importante na composição do bloco sindicalista no Congresso Nacional foi a expulsão de dois parlamentares petistas (um deputado e uma senadora) que votaram contra a PEC Principal. Assim, no trâmite legislativo da PEC Paralela, a bancada sindical petista na Câmara passou de 44 para 43 deputados, enquanto, no Senado Federal, o bloco sindicalista do PT caiu de 5 para 4 senadores. Os demais partidos mantiveram o mesmo número de parlamentares de origem sindical: Partido Comunista do Brasil (PCdoB) (7); Partido Democrático Trabalhista (PDT) (1); Partido Popular Socialista (PPS) (1); Partido Progressista Brasileiro (PPB) (1) e Partido da Frente Liberal (PFL) (1).

Tabela 1

Número de Sindicalistas por Partido Político Câmara e Senado (2004)

\begin{tabular}{lccc}
\hline Partido & Câmara & Senado & Total \\
\hline PT & 42 & 4 & 46 \\
\hline PCdoB & 7 & 0 & 7 \\
\hline PDT & 1 & 0 & 1 \\
\hline PPS & 1 & 0 & 1 \\
\hline PPB & 1 & 0 & 1 \\
\hline PFL & 1 & 0 & 1 \\
\hline Sem Partido & 2 & 1 & 3 \\
\hline Total & 55 & 5 & 60 \\
\hline
\end{tabular}

Fonte: Departamento Intersindical de Assessoria Parlamentar (DIAP).

Elaborada pelo autor. 
Mas, se por um lado, a base governista (mais especificamente a bancada parlamentar do PT), perdeu dois parlamentares sindicalistas: o deputado João Batista (Babá) e a senadora Heloísa Helena, por outro, houve um reforço da participação sindical no processo decisório da reforma da Previdência. Tal fato fica evidenciado, por exemplo, no papel de destaque ocupado pelos senadores sindicalistas Paulo Paim (PT/RS) e Ideli Salvatti (PT/SC) na formulação e aprovação da PEC 77/2003.

Na Câmara dos Deputados, o bloco sindicalista também contava com cargos estratégicos para uma participação qualificada no debate da PEC Paralela, a começar pela própria presidência da Casa, ocupada pelo ex-metalúrgico João Paulo Cunha (PT/SP). Além disso, o relator do projeto na Comissão Especial da Previdência (CESP), deputado José Pimentel (PT/CE), o líder do governo na Câmara dos Deputados, prof. Luizinho (PT/SP) e o líder do Partido dos Trabalhadores (principal partido da base governista), deputado Arlindo Chinaglia (PT/SP), também eram integrantes da bancada sindical.

O entendimento entre os líderes, por sua vez, é de fundamental importância para se superar frequentes impasses regimentais que ocorrem ao longo do processo decisório de uma política pública. As lideranças partidárias cumprem papel relevante na definição "do que", "quando" e "como" será discutido uma determinada proposição (Figueiredo e Limongi, 2001; Pereira e Mueller, 2000; Santos e Almeida, 2011).

Por meio de acordo dos líderes é possível reduzir o número de sessões para analisar uma determinada matéria, enviá-la diretamente para apreciação do plenário, retirar ou postergar a análise de destaques e proposições apresentadas por outros parlamentares etc. Em outras palavras, por meio de acordo de lideranças, é possível destravar ou dar maior celeridade à apreciação de uma determinada matéria ou, inversamente, arquivá-la ou reduzir o seu ritmo de apreciação quando não há consenso sobre o tema.

Em resumo, pela primeira vez desde a promulgação da Constituição de 1988, os parlamentares sindicalistas ocupavam um lugar privilegiado na Câmara dos Deputados e no Senado Federal para influenciar diretamente o processo decisório da política previdenciária. Como veremos nas próximas seções deste artigo, essa posição singular per- 
mitiu aos deputados e senadores de origem sindical minimizarem os efeitos negativos da reforma previdenciária sobre os funcionalismos públicos federal, estadual e municipal.

\section{SINDICALISMO E PROCESSO DECISÓRIO}

Em trabalhos anteriores (Jard da Silva, 2007a; 2007b), analisei comparativamente a participação dos parlamentares sindicalistas no processo decisório da reforma da Previdência na Argentina e no Brasil. O principal objetivo era identificar as condições político-institucionais que favoreciam a emergência de um padrão negociado de reforma previdenciária entre representantes dos trabalhadores e do governo.

No Brasil, durante o governo de Fernando Henrique Cardoso (19952002), os parlamentares sindicalistas, em sua grande maioria nos partidos de oposição (PT e PCdoB), foram disciplinadamente contrários à proposta de reforma da Previdência enviada ao Legislativo por um Executivo considerado adversário da bancada sindical. Na Argentina, durante a administração de Carlos Saúl Menem (1989-1999), os parlamentares sindicalistas, majoritariamente peronistas (Partido Justicialista - PJ), romperam com o Executivo considerado aliado e se juntaram à oposição para exigir alterações no projeto de reforma previdenciária enviado ao Legislativo - episódio que ficou conhecido como aliança sindical-radical, em referência à aproximação dos deputados sindicalistas aos parlamentares da Unión Cívica Radical (UCR), principal partido de oposição ao governo (Alonso, 1998; Llanos, 1998).

A estratégia da bancada sindical argentina foi bem-sucedida e logrou importantes concessões não apenas na área previdenciária, mas também na área trabalhista na qual o governo Menem havia implementado mudanças unilaterais contrárias aos interesses do sindicalismo. Entre as conquistas mais importantes destacavam-se: i) a supervisão tripartite do sistema previdenciário; ii) a participação sindical na gestão dos fundos de pensão; iii) a regulamentação da negociação coletiva no setor público; e iv) a revisão da desregulamentação do Sistema de Obras Sociales (Jard da Silva, 2007a; 2007b).

Dez anos depois, quando o ex-sindicalista Luiz Inácio Lula da Silva chegou à Presidência da República e enviou ao Congresso Nacional uma proposta de reforma da Previdência que resgatava e dava conti- 
nuidade há muitos pontos derrotados no processo decisório da reforma previdenciária do seu antecessor, Fernando Henrique Cardoso, trabalhei inicialmente com a hipótese de que se repetiria no legislativo brasileiro uma aliança nos moldes do bloco "sindical-radical" argentino.

Na minha avaliação preliminar, inspirada na experiência argentina, a bancada sindical romperia temporariamente com o governo considerado aliado para exigir concessões no projeto de reforma da Previdência enviado ao Congresso Nacional, mesmo que para tanto fosse preciso se aliar aos partidos de oposição. Em poucas palavras, se repetiria no Brasil de Lula o que ocorreu na Argentina de Menem.

O raciocínio invocado naquele momento era relativamente simples: se em um sistema político bipartidário, em que o governo necessitava apenas de maioria simples para aprovar a sua proposta de reforma previdenciária, o sindicalismo argentino foi capaz de lograr importantes concessões do gobierno amigo (Menem); em um sistema político multipartidário, em que o Executivo necessitava de maioria qualificada para aprovar a reforma da Previdência, o sindicalismo brasileiro seria igualmente capaz de negociar e lograr importantes concessões por parte do governo aliado (Lula) ${ }^{12}$.

No entanto, pelo menos em um primeiro momento, a hipótese não se confirmou. Durante o trâmite inicial da PEC 40/2003, os deputados sindicalistas seguiram disciplinadamente as lideranças partidárias e votaram a favor do projeto de reforma da Previdência enviado pelo Executivo (Jard da Silva, 2016). Mais do que isso, a própria oposição se dividiu, e uma parte considerável dos deputados do PFL e do Partido da Social Democracia Brasileira (PSDB) votou a favor da reforma previdenciária $^{13}$. Nas palavras de Melo e Anastasia:

Se Fernando Henrique enfrentou uma oposição coesa e disciplinada durante a votação da PEC nº 33, com Lula, exceção feita ao Prona, o quadro foi muito distinto. PSDB e PFL apresentaram-se cindidos ao meio, independentemente da orientação estabelecida pelo líder. (2006:318)

Assim, a aliança "sindical-oposição" brasileira se daria só mais tarde, na segunda fase de tramitação da reforma da Previdência no Legislativo. Foi no Senado Federal, onde o governo Lula contava com uma maioria mais estreita, que os parlamentares sindicalistas vislumbraram 
a oportunidade de se aliar à oposição e exigir concessões no projeto original da reforma da Previdência. As dificuldades encontradas pelo Executivo para reunir a maioria qualificada para aprovar a sua proposta na Casa Revisora foi salientada, em 11 de dezembro, pelo senador Arthur Virgílio, líder do PSDB no Senado:

\begin{abstract}
Mas nós temos procurado mostrar que quem pode muito porque ganhou a eleição não pode tudo somente porque ganhou a eleição, até porque nós existimos, numa correlação de forças, que é mais favorável à Oposição aqui do que na Câmara. Nós temos um número que é muito expressivo em relação aos quarenta e um que seriam necessários para termos a maioria. E o Governo não tem muito mais do que quarenta e um para expressar a sua maioria. O Governo teve que fazer todos os acordos e conchavos. E fez. (Diário do Senado Federal, 2003:40730)
\end{abstract}

O fato é que tão logo chegou à Casa Revisora, e até mesmo antes disso, senadores da bancada sindical e da oposição anunciaram que iriam realizar mudanças no projeto enviado pela Câmara de Deputados. No entanto, a alteração da proposta original obrigaria o retorno do projeto à primeira Casa e a mais uma desgastante rodada de negociações para ser aprovada em dois turnos com maioria qualificada ${ }^{14}$.

Diante do impasse e da iminente derrota do projeto original no Senado, o Executivo foi obrigado a fazer concessões à aliança sindical-oposição. Para evitar que a proposta da reforma da Previdência fosse alterada na Câmara Alta e voltasse à Câmara Baixa, o governo aceitou negociar os termos de uma PEC Paralela, a qual recepcionaria as principais propostas da bancada sindical e da oposição, desde que não houvesse alteração no texto da PEC Principal. Tratava-se de uma saída política inédita para superar um importante imbróglio entre Executivo e Legislativo no processo decisório da reforma previdenciária.

O mérito e o sucesso da aliança sindical-oposição foram ressaltados e mutuamente celebrados tantos pelos parlamentares da bancada sindical quanto pelos integrantes da bancada de oposição. Nas palavras do senador Paulo Paim (PT/SP), em 11 de dezembro de 2003:

A PEC no 77 existe, porque 25 senadores, que votaram contra [a PEC $67 / 2003$ ], ajudaram a construí-la, assim como todos aqueles que votaram a favor. Então, a PEC no 77 não é mérito da Situação ou da Oposição, mas 
fruto de um amplo acordo desta Casa. E repito: a Oposição foi fundamental para construir esse grande entendimento. (Diário do Senado Federal, 2003:40714)

As palavras dos senador Paulo Paim (PT/RS) foram saudadas por vários senadores da oposição, entre eles o líder do PSDB, senador Arthur Virgílio (PSDB/AM):

\begin{abstract}
Por isso, ainda assim, comemoro o fato de que alguma conquista se fez por força da Oposição, e a Oposição, resistindo, fez com que o Governo procurasse segmentos seus que estavam rebelados, fazendo concessões a eles para viabilizar a aprovação da PEC nํㅡ 67, da PEC principal. Ou seja, não foi possível avançar muito, porque não tínhamos força numérica para avançar mais. Deu para avançar, meu Presidente, Senador Paulo Paim, o que era possível. Estamos, portanto, não digo comemorando, mas registrando que a Oposição se considera co-responsável pelo avanço mínimo e possível. (Diário do Senado Federal, 2003:40730)
\end{abstract}

Em uma conjuntura político-institucional marcada pela preponderância do Executivo na formulação de políticas públicas, essa aliança chamou atenção pelo inédito protagonismo assumido pelo Legislativo no processo decisório da política previdenciária e, para fins deste artigo, pelo papel de destaque ocupado pelos parlamentares sindicalistas no processo de negociação da PEC Paralela da Previdência entre o governo e a oposição.

É igualmente digno de nota o protagonismo do Senado Federal na condução do processo decisório da PEC 77/2003. Enquanto as reformas previdenciárias anteriores, por terem sido de iniciativa do Executivo, começaram a sua tramitação obrigatoriamente pela Câmara dos Deputados, dessa vez, por ter sido formulada na Câmara Alta, caberia aos deputados cumprirem o papel de "revisores" da matéria.

Nesse ponto vale ressalvar que, ainda que fosse dada como certa a aprovação da PEC Principal no Senado, era grande a incerteza em torno da aprovação da PEC Paralela na Câmara. Nesse sentido, era forte o apelo para que os senadores aprovassem a nova proposta de emenda constitucional por unanimidade e da forma mais célere possível para que não houvesse um grande interregno entre a aprovação da 
PEC Principal no Senado e a votação da PEC Paralela na Câmara, com intuito de demonstrar que a aprovação da PEC 77/2003 nas duas Casas deveria ser a prioridade do Congresso Nacional naquela legislatura.

No Senado Federal, a PEC Paralela tramitou por exatos três meses (90 dias). Nas diferentes instâncias de tramitação, o maior tempo de apreciação da matéria coube à Comissão de Constituição, Justiça e Cidadania (CCJ): 56 dias. No Plenário da Casa, por sua vez, a proposição foi apreciada e aprovada, por unanimidade em dois turnos de votação, em apenas 13 dias. Em primeiro turno, recebeu 69 votos favoráveis e nenhum contrário. No segundo, nenhum voto contra e 64 a favor.

O consenso na votação e a célere tramitação em Plenário parecia ser um forte indicativo da efetividade do acordo costurado entre a base do governo e a oposição para aprovar a "reforma da reforma" da Previdência do governo Lula. Na construção desse acordo político, destacaram-se desde o início os senadores de origem sindical Paulo Paim, Ideli Salvatti e Heloisa Helena - todos, até então, filiados ao PT. Muito embora tenham apresentado posicionamentos distintos e diferentes intensidades de envolvimento na construção da PEC Paralela, todos concordavam que a PEC 77/2003 era a única forma possível de minimizar as perdas impostas aos servidores públicos pela recém-aprovada PEC 67/2003.

A senadora Heloísa Helena, enfrentando um processo de expulsão dentro do PT por ter votado contra a PEC Principal, foi aquela que apresentou a postura mais crítica de denúncia do caráter "conservador" da proposta original do governo Lula. Paulo Paim, por sua vez, foi o grande articulador do acordo entre a base do governo e a oposição, envolvendo os parlamentares "rebeldes" do seu partido e entidades representativas dos servidores públicos. Finalmente, Ideli Salvatti, como a então líder do PT no Senado, apresentou e afiançou a proposta da PEC Paralela entre os partidos da base governista.

\section{"NAS PARALELAS"}

O início da tramitação da PEC 77/2003 na Câmara dos Deputados (agora sob o número 227/04) parecia confirmar os receios e as desconfianças dos servidores públicos e suas entidades representativas em relação ao efetivo compromisso do governo com a aprovação da nova emenda 
constitucional (Jard da Silva, 2016). De fato, não obstante o acordo firmado com o bloco sindical e com a oposição, a bancada governista tentou inserir na PEC Paralela parte do texto da PEC Principal.

Nesse ponto, vale a pena ressaltar que a demora para a aprovação da PEC Paralela na Câmara dos Deputados não era uma grande preocupação para o Executivo, haja vista que as medidas promulgadas pela PEC Principal já estavam em vigor. Aliás, quanto mais demorasse para ser aprovada a "reforma da reforma", melhor seria para o governo em termos de redução dos seus gastos imediatos com o regime próprio do funcionalismo.

Assim, conforme registra a Tabela 2, se no Senado Federal foram necessários apenas três meses para a aprovação da PEC Paralela da Previdência, na Câmara dos Deputados, a mesma matéria, igualmente afiançada por parlamentares da oposição e da bancada sindical, levou mais de um ano para ser aprovada.

Tabela 2

Sumário da Tramitação da PEC 77/2003

\begin{tabular}{lll}
\hline Início & Tramitação & Dias \\
\hline Senado & & \\
\hline $08 / 10 / 2003$ & Apresentação do Projeto & 01 \\
\hline $09 / 10 / 2003$ & Apreciação na CCJ & 56 \\
\hline $04 / 12 / 2003$ & Plenário & 13 \\
\hline $17 / 12 / 2003$ & Encaminhamento para a Câmara dos Deputados & 20 \\
\hline & Total & 90 \\
\hline Câmara & & \\
\hline $06 / 01 / 2004$ & Apresentação do Projeto & 01 \\
\hline $07 / 01 / 2004$ & Encaminhamentos Administrativos & 05 \\
\hline $12 / 01 / 2004$ & Apreciação na CCJC & 23 \\
\hline $05 / 02 / 2004$ & Encaminhamentos Administrativos & 05 \\
\hline $11 / 02 / 2004$ & Apreciação na CESP & 77 \\
\hline $29 / 04 / 2004$ & Plenário & 321 \\
\hline & Total & 432 \\
\hline
\end{tabular}

Fonte: Câmara dos Deputados (Atividade Legislativa). Elaboração do autor. 
O distinto tratamento da matéria nas comissões legislativas da Câmara dos Deputados foi o primeiro sinal das dificuldades enfrentadas pelos parlamentares da base sindical e da oposição para manter o acordo que havia sido firmado no Senado Federal. Muito embora tenha apresentado um trâmite relativamente rápido na CCJC (23 dias), o projeto levou mais 77 dias para ser apreciado na Comissão Especial da Previdência (CESP) e quase um ano (321 dias) para ser apreciado e aprovado no plenário da Casa. É igualmente digno de nota o fato de que, enquanto na CCJC o parecer do deputado Maurício Rands (PT/ PE) foi aprovado por unanimidade ${ }^{15}$, na CESP o parecer do deputado José Pimentel (PT/SP), outro destacado membro da bancada sindical, sequer foi votado.

Na CCJC, a base do governo reunia a ampla maioria dos deputados: 35 dos 57 integrantes $(61,40 \%)$. Entre os quais, um integrante da bancada sindical, prof. Luizinho (PT/SP). Na CESP, por sua vez, contava com 23 integrantes, em um total de 39 deputados (58,97\%). Nessa última comissão, a bancada sindical tinha seis deputados: Arlindo Chinaglia (PT/SP), dr. Rosinha (PT/PR), Eduardo Valverde (PT/RO), Ivan Valente (PT/SP), Jandira Feghali (PCdoB/RJ) e José Pimentel (PT/CE).

Em ambas as comissões o governo reunia a maioria necessária para aprovar a nova Proposta de Emenda Constitucional da Previdência. No entanto, o alinhamento dos parlamentares seja ao lado do governo, seja nas fileiras da oposição, não é linear nem automático. De fato, conforme argumentam Palermo (2016, 2000) e Silveira e Silva (2014), as maiorias são construídas politicamente.

A pressão pela aprovação da PEC 227/2004 sem alterações partia fundamentalmente dos parlamentares sindicalistas que respaldaram o acordo firmado entre situação e oposição no Senado Federal, e de setores do funcionalismo (ativos e inativos) que já estavam sofrendo os efeitos negativos da implementação da reforma da Previdência recém-promulgada pelo Congresso Nacional.

Ao longo do processo de negociação, pressionados pela bancada sindical e pelas entidades representativas dos servidores públicos, os líderes partidários apresentaram um requerimento de envio da PEC 227/2004 diretamente ao Plenário da Casa. A proposição utilizou como precedente legislativo um ato do ex-presidente da Câmara dos Deputados, Luís Eduardo Magalhães (PFL/BA): 
Invocamos, nesse sentido, os precedentes estabelecidos pela Decisão do Presidente Michel Temer, em resposta à Questão de Ordem no 10.082 , referente à PEC no 472, de 1997, bem como o Ato do Presidente Luís Eduardo, de 08 de fevereiro de 1996, que determinou o envio a Plenário da PEC 33, de 1995. (Brasil, Requerimento $\mathrm{n}^{\mathrm{o}}$ 1.781, de 29 de abril de 2004)

O resgate do referido requerimento é um indicativo de que "a troca de lugares entre situação e oposição" (Melo e Anastasia, 2006:305) não apenas afetou as preferências dos atores partidários em relação ao conteúdo da reforma da Previdência, mas também a própria percepção desses atores sobre os métodos a serem empregados na apreciação da matéria. Durante a reforma da Previdência do governo de Fernando Henrique Cardoso, o mesmo expediente foi duramente criticado pelos principais partidos da oposição (PT, PCdoB e PDT) como discriminatório e sem amparo no regimento interno da Casa (Figueiredo e Limongi, 1998). Portanto, uma medida outrora contestada pelos partidos de oposição no governo FHC foi retomada como "precedente estabelecido" quando os mesmos partidos passaram para a situação no governo Lula.

Encaminhada diretamente para o plenário da Câmara, iniciou-se um novo e longo período de debate em torno da PEC 227/2004. No centro da disputa parlamentar estava a decisão do relator da matéria, deputado José Pimentel (PT/SP), de apresentar um Substitutivo Global à PEC Paralela, o qual alterava pontos importantes do acordo anteriormente firmado entre a base governista e a oposição no Senado Federal, e remetia parte da matéria para ser regulamentada por legislação infraconstitucional. Nas palavras do próprio relator:

Estamos também fazendo uma série de supressões nesta PEC Paralela, porque já regulamentamos essa matéria na Lei no 10.887 , já em vigor, particularmente no que trata da unidade gestora da União, dos estados e dos municípios. Aprovamos, no projeto de conversão da Medida Provisória no 167 , a constituição da unidade gestora paritária, em que uma metade será indicada pelo empregador, seja município, estado, seja União, e a outra será eleita pelo funcionalismo. Esse mecanismo será definido em regulamento interno. Ou seja, como se dará essa composição entre a União e os Três Poderes: Executivo, Legislativo e Judiciário. Como esta matéria já está disciplinada na Lei no 10.887 e por ser matéria infraconstitucional, nós a transferimos para essa Lei. (Câmara dos Deputados, 2004:32243) 
A apresentação do substitutivo desagradou profundamente os parlamentares que afiançaram o texto original da PEC Paralela. Não obstante, ainda que em um ritmo muito mais lento do que aquele observado entre os senadores, tanto os deputados da base sindical quanto os da oposição passaram a trabalhar para manter o compromisso político de minimizar as perdas impostas ao funcionalismo pelo projeto original da reforma da Previdência.

Nesse ponto, vale destacar que o papel de guardião do acordo político construído no Senado Federal foi exercido, principalmente, pelos parlamentares da oposição e pelos deputados expulsos do PT. A bancada sindical limitou-se a fazer críticas pontuais ao substitutivo do relator sem, no entanto, exigir que fosse votada a Proposta de Emenda Constitucional elaborada por iniciativa dos senadores sindicalistas, tal como exigia a oposição e os dissidentes da base petista.

Ao longo do processo de negociação, apenas um ponto do substitutivo continuou a ser fortemente criticado e questionado pelos parlamentares da oposição e dissidentes petistas, mas também por parlamentares da própria base governista: a decisão de não estender a paridade para as futuras pensões de aposentados que haviam cumprido os requisitos previstos na PEC 77/2003. A discussão sobre a extensão da paridade para os futuros pensionistas criou um ambiente de grande tensão entre os parlamentares defensores da aprovação da PEC Paralela do Senado Federal e os parlamentares favoráveis à aprovação do Substitutivo Global da Câmara dos Deputados.

A saída para o impasse foi, mais uma vez, costurada por meio de um acordo político entre a base do governo e a oposição no qual foi de fundamental importância o papel de mediador de conflitos assumido pelo então presidente da Casa, deputado João Paulo Cunha (PT/SP). Ao longo da tramitação da matéria, limitada pelas regras procedimentais que restringiam o avanço da proposição legislativa, diversas vezes o presidente da Câmara conclamou as lideranças partidárias a firmarem acordos que flexibilizassem a implementação do regimento interno. Por fim, também com o imprescindível respaldo das lideranças partidárias acordou-se deixar para a votação de destaque em separado os pontos que não eram consensuais na PEC Paralela da Previdência ${ }^{16}$. 
Superadas as principais divergências em torno do Substitutivo Global, o acordo político firmado pelos senadores e respaldado pelos deputados prevaleceu sobre as tentativas do governo de recuperar o seu projeto original de reforma da Previdência. Destaca-se, na Tabela 3, o elevadíssimo número de votos favoráveis recebidos pela PEC Paralela tanto por deputados da situação quanto da oposição.

Tabela 3

Porcentagem de votos "sim" na PEC 227/2004

Plenário da Câmara, Base do Governo, Bancada Sindical

\begin{tabular}{lccc}
\hline & 10 Turno $^{\circ}$ & 20 Turno $^{\circ}$ & Média \\
\hline Plenário da Câmara & 98,4 & 99,8 & 99,1 \\
\hline Base do Governo & 98,8 & 100,00 & 99,4 \\
\hline Bancada Sindical & 100,0 & 100,0 & 100 \\
\hline
\end{tabular}

Fonte: Diário da Câmara dos Deputados. Elaborada pelo autor.

A PEC 227/2004 foi aprovada com expressiva maioria nos dois turnos de votação no Plenário da Câmara ${ }^{17}$. No primeiro turno, a proposição recebeu $98,4 \%$ de votos favoráveis ${ }^{18}$. Na base governista e na bancada sindical, recebeu, respectivamente, $98,8 \%$ e 100,0\% de votos "sim". Já no segundo turno, não fosse a abstenção do deputado Roberto Brant (PFL/MG), ex-ministro da Previdência do governo de Fernando Henrique Cardoso, a PEC Paralela teria sido aprovada por unanimidade.

O quase consenso em torno da matéria revela a força do acordo político construído entre os senadores e reiterado pelos deputados da base governista e da oposição, com destaque para o papel da bancada sindical como fiadora do referido acordo junto aos servidores públicos. Muito embora a tramitação na Câmara não tenha sido tão célere como no Senado, o conteúdo principal da proposição legislativa foi mantido, mesmo diante da tentativa do Executivo de rever alguns pontos inicialmente acordados com os sindicalistas da base e os deputados da oposição.

Em síntese, muito embora a tramitação da PEC 77/2003 na Câmara dos Deputados não tenha sido tão célere e consensual como esperavam os seus idealizadores no Senado Federal, e mesmo sofrendo algumas alterações, a proposta contruída por intermédio de um grande acordo político entre senadores da base e da oposição foi mantida em sua essência. Uma vitória particularmente importante para os parla- 
mentares sindicalistas, especialmente senadores, que enfrentaram não apenas as manobras protelatórias do Executivo, mas também a própria desconfiança dos servidores públicos em relação à efetiva aprovação da matéria no Congresso Nacional.

\section{CONSIDERAÇÕES FINAIS}

A maior parte dos trabalhos realizados sobre o processo decisório da reforma da Previdência no governo de Luiz Inácio Lula da Silva concentram suas análises no trâmite legislativo da Proposta de Emenda à Constituição nº 40, de 2003 (PEC 40/2003). De forma geral, esses trabalhos foram unânimes em afirmar o sucesso do governo petista na aprovação da reforma previdenciária e a predominância do Executivo sobre o Legislativo (Hiroi, 2008; Nakahodo e Savoia, 2008; Melo e Anastasia, 2006).

A maioria das pesquisas sobre o tema sequer menciona que "paralelamente" ao processo de aprovação da PEC 40/2003 (PEC Principal) foi apresentada no Senado Federal uma nova proposta de reforma da Previdência que tinha como objetivo alterar pontos importantes da proposição legislativa ainda em tramitação no Congresso $\mathrm{Nacional}^{19}$.

A análise do trâmite legislativo da Proposta de Emenda à Constituição no 77, de 2004, conhecida como PEC Paralela, relativiza o sucesso do governo petista e a predominância do Executivo no processo decisório da reforma da Previdência do governo Lula. Como demonstrado ao longo deste artigo, o projeto original da reforma previdenciária só foi aprovado sob a condição de ser imediatamente revisto por uma nova Proposta de Emenda Constitucional.

Diante das dificuldades para aprovar a reforma da Previdência na própria base governista, especialmente entre os senadores sindicalistas, o Executivo foi obrigado a negociar um acordo com a bancada sindical e os partidos de oposição que previa apresentação de uma nova Emenda Constitucional, reduzindo os efeitos da reforma a ser aprovada. Em poucas palavras, a "reforma da reforma" foi condição prévia para a aprovação da PEC 40/2003.

Assim sendo, qualquer análise do processo decisório da reforma previdenciária do governo Lula que não compreenda o processo de negociação em torno da PEC Principal (PEC 40/2003) e, conjuntamente, da 
PEC Paralela (PEC 77/2003), revela-se incompleta e sujeita a superestimar o sucesso e a predominância do Executivo sobre o Legislativo. A austeridade da PEC Principal em relação aos benefícios previdenciários dos servidores públicos tinha prazo de validade previamente estabelecido: a aprovação da PEC Paralela.

Pela primeira vez, desde a malograda revisão constitucional de 1993, o Legislativo foi bem-sucedido na apresentação e na aprovação de uma proposta constitucional de reforma da Previdência. Destaca-se, nesse caso, o papel do Senado Federal enquanto instância de negociação e formulação de alternativas ao projeto original do Executivo, que tinha sido aprovado na Câmara dos Deputados com disciplinado empenho da base governista e apoio de setores da oposição.

Igualmente digno de nota é o protagonismo da bancada de senadores sindicalistas no processo de articulação e negociação de um acordo político envolvendo parlamentares da situação e da oposição com o objetivo de minimizar os efeitos negativos da reforma da Previdência sobre os servidores públicos. Os mesmos parlamentares, com destaque para a figura do senador Paulo Paim (PT/RS), principal articulador da PEC Paralela, foram de fundamental importância para legitimar a proposta de "reforma da reforma" junto ao funcionalismo público.

Assim, muito embora a bancada de deputados e senadores sindicalistas tenha se mantido fiel à orientação da base governista no que se refere ao voto favorável à reforma da Previdência, é imprescindível notar que o voto a favor da reforma previdenciária foi resultado de um intenso e tenso processo de negociação que passou por uma solução de compromisso que previa a imediata revisão das medidas recém-aprovadas. Parafraseando Melo e Anastasia (2006), a reforma da Previdência do governo Lula foi realizada "em dois tempos".

No primeiro tempo, na Câmara dos Deputados, o governo teve domínio de jogo. Entretanto, no segundo tempo, o Senado Federal apresentou-se como instância de veto que obrigou o Executivo a fazer concessões importantes na sua proposta de reforma da Previdência sem, no entanto, alterar o texto da PEC Principal. O ineditismo dessa solução parlamentar foi materializado na proposta de PEC Paralela formulada e articulada pela bancada de senadores sindicalistas. $\mathrm{O}$ 
placar final parece indicar muito mais um empate do que uma vitória do governo petista. Não por acaso, o jogo da reforma da Previdência continuou (e continua) a ser jogado pelos governos que o sucederam ${ }^{20}$.

(Recebido para publicação em 1으 de setembro de 2018)

(Reapresentado em 5 de março de 2020)

(Aprovado para publicação em 9 de maio de 2020)

\section{NOTAS}

1. Neste ponto, vale a pena relembrar a célebre passagem da "Carta de Nicolau Maquiavel ao Magnífico Lourenço de Médici", em O Príncipe: "Os que desenham os contornos dos países se colocam na planície para considerar a natureza dos montes, e para considerar a das planícies ascendem aos montes" (Maquiavel, 1983[1515]:3-4).

2. Nas palavras dos próprios autores: "De um governo para outro, partidos como o PT, o PCdoB, o PSDB e o PFL passaram a viver uma situação que pode ser caracterizada pelo fato de suas antigas preferências no que se refere à política previdenciária terem se tornado contraditórias com suas posiç̃os nas arenas parlamentar e governamental." (Melo e Anastasia, 2005:305)

3. Análises mais abrangentes da onda de reformas previdenciárias que atingiu o Brasil e outros países da América Latina nas últimas décadas podem ser encontradas em Coelho (2003, 2001), Kay e Sinha (2008), Madrid (2003), Sinha (2000).

4. Ferraz (2018:194) registra que "O contexto político marcado pela reforma da Previdência, em 2003, contribuiu para que, em 2004, grupos ligados ao Partido Socialista dos Trabalhadores Unificado (PSTU) e à corrente intersindical saíssem da CUT para fundar a Coordenação Nacional de Lutas (Conlutas)." Mais tarde, em 2006, seria criada a Intersindical, vinculada ao Partido Socialismo e Liberdade (PSOL), este último também fruto da reconfiguração do movimento sindical e da esquerda brasileira no pós-reforma da Previdência. Análise semelhante é encontrada em Ladosky e Jácome Rodrigues (2018).

5. Em alguns casos específicos, o Poder Judiciário também pode ser instado a se manifestar sobre os aspectos constitucionais das decisões tomadas e das matérias aprovadas.

6. Referindo-se especificamente à relação do sindicalismo cutista com os governos petistas, Carvalho e Costa (2018:170) apresentam questões semelhantes: "O que acontece quando a ideologia sindical se aproxima da governamental? $\mathrm{Ou}$, dito de outro modo, no caso brasileiro, que desafios se colocaram à Central Única dos Trabalhadores (CUT) quando o Partido dos Trabalhadores (PT) ascendeu ao poder?"

7. A PEC 77/2003 foi formalmente apresentada pela senadora Ideli Salvatti (PT/SC), então líder do PT no Senado Federal, e teve como relator o senador Tião Viana (PT/AC).

8. Não é objetivo deste artigo discutir a atuação sindical fora do Poder Legislativo. Para uma revisão sobre o sindicalismo brasileiro nas últimas décadas, ver: Carvalho e Costa (2018); Ferraz (2018, 2014); Ladosky e Jácome Rodrigues (2018); Cardoso e Gindin (2017); Antunes e Silva (2015); Jácome Rodrigues (2015); Jard da Silva (2013); Ramalho (2011); Bautista (2010); Santana e Braga (2009); Bridi (2006). Sobre o sindicalismo internacio- 
nal, ver: Estanque, Costa e Silva (2015); Costa (2014, 2011, 2002); Estanque (2011, 2009); Estanque e Ferreira (2002); Ferreira (2002); Hyman (2002); Waterman (2002); Murillo $(2001,2000)$.

9. Uma excelente análise da ascensão dos sindicalistas a altos cargos do Executivo e do Legislativo durante o governo de Luiz Inácio Lula da Silva pode ser encontrada em Martins Rodrigues (2009) e em Martins Rodrigues e Sadek (2010).

10. Neste ponto, é importante assinalar que, no decorrer da tramitação do projeto no Senado Federal, importantes entidades representativas dos servidores públicos haviam assinado a "Carta aos senadores sobre a PEC Paralela", com duras críticas ao acordo costurado entre governo e oposição para a aprovação da matéria.

11. Novo número recebido pela PEC Paralela da Previdência na Câmara dos Deputados.

12. Para uma análise comparativa mais aprofundada sobre o sistema político argentino e brasileiro, ver: Jard da Silva e Diniz (2009).

13. Neste ponto, cabe destacar, como também o fazem Melo e Anastasia (2006), que Lula obteve o importante apoio dos governadores eleitos pelo PSDB e PFL, e de suas respectivas bancadas estaduais no Congresso Nacional, ao seu projeto de reforma previdenciária.

14. Sobre as regras internas do processo legislativo brasileiro, ver: Figueiredo e Limongi (1996) e Pacheco e Mendes (2017).

15. Ressalva-se apenas o "voto em separado não divergente das conclusões do Relator", apresentado pelo deputado Sérgio Miranda (PCdoB/MG), no que se refere à constitucionalidade da contribuição dos inativos.

16. Apresentado como Destaque para Votação em Separado (DVS), respaldado pela oposição, pelos dissidentes petistas e pelos setores da própria base do governo, a proposta de extensão da paridade para as futuras pensões recebeu 305 votos favoráveis, uma quantidade muito próxima do mínimo de 308 votos exigido para a aprovação de uma Emenda Constitucional.

17. No primeiro turno de votação, com a exceção do Prona, todos os demais partidos orientaram voto favorável à PEC Paralela. No segundo turno, todos os partidos indicaram voto "sim", inclusive o Prona.

18. Votaram contra os deputados Arnaldo Faria de Sá (PTB/SP), Elimar Máximo Damasceno (Prona/SP), Enéas (Prona/SP), Mendes Ribeiro Filho (PMDB/RS) e Onyx Lorenzoni (PFL/RS). O deputado José Correia (PMDB/AC) se absteve.

19. Neste ponto, devo admitir que em trabalho anterior, muito embora tenha mencionado as negociações em torno da PEC Paralela, seguindo a corrente principal da literatura sobre o tema, também não me dei conta da sua importância para a aprovação da PEC Principal (Jard da Silva, 2016).

20. No momento em que finalizo este artigo, uma nova PEC Paralela da Previdência, Proposta de Emenda à Constituição no 133 (PEC 133/2019), elaborada e aprovada no Senado Federal, tramita na CCJC da Câmara dos Deputados. Parafraseando o velho Karl Marx, "todos os grandes fatos e todos os grandes personagens da história mundial são encenados, por assim dizer, duas vezes." (Marx, 2011 [1852]) 


\section{REFERÊNCIAS}

ALONSO, Guillermo V. (1998), “Democracia y reformas: las tensiones entre decretismo y deliberación. El caso de la Reforma Previsional Argentina". Desarrollo Económico. vol. 38, $\mathrm{n}^{\mathrm{o}} 150$, pp. 595-626.

ANTUNES, Ricardo; SILVA, Jair Batista da. (2015), "Para onde foram os sindicatos? Do sindicalismo de confronto ao sindicalismo negocial". Caderno $C R H$, vol. 28, $\mathrm{n}^{\circ} 75$, pp. 511-527. Disponível em https:/ /dx.doi.org/10.1590/S0103-49792015000300005.

ARMIJO, Leslie; FAUCHER, Philippe; DEMBINSKA, Magdalena. (2006), “Compared to what? Assessing Brazil's Political Institutions". Comparative Political Studies, vol. 39, no6, pp. 759-786.

BRIDI, Maria A. (2006), “As várias manifestações de crises no sindicalismo e a crítica ao pensamento generalizante de crise”. In: S. M. de Araújo; M. A. Bridi; M. Ferraz (orgs.), O sindicalismo equilibrista: entre o continuísmo e as novas práticas. Curitiba: UFPR/SCHLA, pp. 281-312.

BAUTISTA, Lucca J. (2010), Estudio comparado sobre la centralidad del trabajo y el sindicalismo en el discurso identitario de Lula da Silva (2003-2006) y Nestor Kirchner (2003-2007). Trabalho apresentado no V Congreso Latinoamericano de Ciencia Política. Buenos Aires, 28-30 de julho.

CARDOSO, Adalberto; GINDIN, Julián. (2017), “O movimento sindical na Argentina e no Brasil (2002-2014)". Revista Sociedade e Estado, vol. 32, n 1, pp. 13-37.

CARVALHO, Fernanda F. de; COSTA, Hermes A. (2018), “A relação do sindicalismo CUT com o governo: dilemas e perspectivas (2003-2016)". Política \& Trabalho, n 49, pp. 170-187.

COELHO, Vera S. P. (2003), A reforma da Previdência social na América Latina. São Paulo: Editora FGV.

. (2001), "Poder Executivo e reforma da Previdência na América Latina". Novos Estudos, n ${ }^{\circ} 61$, pp. 93-108.

. (1999), "A reforma da Previdência e o jogo político no interior do Executivo". Novos Estudos, n ${ }^{\circ} 55$, pp. 121-142.

COSTA, Hermes A. (2014), “O sindicalismo em questão em tempos de austeridade". In: R. V. de Oliveira; M. A. Bridi; M. Ferraz (orgs.), O sindicalismo na era Lula: paradoxos, perspectivas e olhares. Belo Horizonte: Fino Traço, pp. 183-210.

. (2011), "Do enquadramento teórico do sindicalismo às respostas pragmáticas". In: E. Estanque; H. A. Costa (orgs.), O sindicalismo português e a nova questão social: crise ou renovação? Coimbra: Almedina, pp. 13-48.

. (2002), “A acção sindical na EU e MERCOSUL: limites e desafios". Revista Crítica de Ciências Sociais, $\mathrm{n}^{\circ}$ 62, pp. 69-95.

COUTINHO, Marcelo J. V. (1998), "Reforma da Previdência: negociações entre os Poderes Legislativo e Executivo". Texto para Discussão, 29, ENAP, 23p. 
ESTANQUE, Elísio. (2011), "Trabalho, sindicalismo e acção colectiva: desafios no contexto de crise". In: E. Estanque; H. A. Costa (orgs.), O sindicalismo português e a nova questão social: crise ou renovação? Coimbra: Almedina, pp. 49-62.

. (2009), "Precariedade, sindicalismo e acção colectiva", in Dois anos a Ferve: retratos da luta, balanço da precariedade. Porto: Afrontamento/FERVE/APRE, pp. 97-101.

ESTANQUE, Elísio; COSTA, Hermes Augusto; SILVA, Manuel Carvalho da. (2015), “O futuro do sindicalismo na representação sociopolítica". In: A. Freire (org.), O futuro da representação política democrática. Lisboa: Nova Vega, pp. 119-142.

ESTANQUE, Elísio; FERREIRA, António. (2002), “Transformações no mundo laboral e novos desafios do sindicalismo português". Revista Crítica de Ciências Sociais, nº 62, pp. 151-188.

FERRAZ, Alexandre S. (2018), "Quando os trabalhadores param? Reinterpretando a ocorrência de greves no Brasil”. Lua Nova, no 104, pp. 167-200.

(2014), "Novos rumos do sindicalismo no Brasil". Revista Brasileira de Ciências Sociais, vol. $29, \mathrm{n}^{\circ} 86$, pp. 109-123.

FERREIRA, Virgínia. (2002), “O efeito Salieri: o sindicalismo perante as desigualdades entre mulheres e homens no emprego". Revista Crítica de Ciências Sociais, nº 62, pp. 121-147.

FIGUEIREDO, Argelina C.; LIMONGI, Fernando. (2001), Executivo e Legislativo na nova ordem constitucional. Rio de Janeiro: FGV.

(1998), "Reforma da Previdência e instituições políticas". Novos Estudos, n 51, pp. 63-90.

. (1996), “Congresso Nacional: organização, processo legislativo e produção legal". Cadernos de Pesquisa, n 5, CEBRAP.

GOMES, Sandra. (2006), “O impacto das regras de organização do processo legislativo no comportamento dos parlamentares: um estudo de caso da Assembléia Nacional Constituinte (1987-1988)". DADOS [online], vol. 49, nº 1, pp. 193-224. Disponível em http:/ / dx.doi.org/10.1590/S0011-52582006000100008.

GONTIJO, José G. L. (2012), “Relação Executivo-Legislativo e processos de retração de provisões sociais: as reformas da previdência de 1998 e 2003 no Brasil". Revista Política Hoje, vol. 21, no 1, pp. 113-149.

HIROI, Taeko. (2008), "Timing and outcome of legislation: Brazilian Pension Reform in a bicameral perspective". Journal of Legislative Studies, vol. 14, n 4, pp. 394-420.

HYMAN, Richard. (2002), "The future of unions". Just Labour, nº 1, pp. 7-15.

IMMERGUT, Ellen M. (1996), “As regras do jogo: a lógica da política de Saúde na França, na Suíça e na Suécia”. Revista Brasileira de Ciências Sociais, vol. 30, n 11, pp. 139-165.

JÁCOME RODRIGUES, Iram. (2015), “Trabalhadores e sindicalismo no brasil: para onde foram os sindicatos?". Caderno CRH, vol. 28, n 75, pp. 479-491. Disponível em https: / / dx.doi.org/10.1590/S0103-49792015000300003.

JARD DA SILVA, Sidney; FERRAZ, Alexandre S. (2019), "Reforma da Previdência em três tempos". Revista Ciências do Trabalho, no 14, pp. 1-10. Disponível em: https:/ / rct.dieese. org.br/index.php/rct/article/view/205/pdf. 
JARD DA SILVA, Sidney. (2018), “Bancada sindical, política previdenciária e processo decisório no Governo Dilma. Revista Brasileira de Ciências Sociais, vol. 33, no 98 [10.05.2019], e339810. Disponível em <http:/ / www.scielo.br/scielo.php?script=sci_ arttext\&pid=S0102-69092018000300508\&lng $=$ en\&nrm $=$ iso $>$.

. (2016), "Unionism, Decision-Making Process and Social Security Reform in Brazil". Brazilian Political Science Review, vol. 10, n 2, Disponível em www.scielo.br/ pdf/bpsr/v10n2/1981-3821-bpsr-10-2-1981-38212016000200002.pdf.

. (2013), Companheiros servidores: o sindicalismo do setor público na CUT. Santo André: UFABC/Fino Traço.

JARD DA SILVA, Sidney; DINIZ, Simone. (2009), “Reforma previsional, sindicalismo y proceso de toma de decisiones en Argentina y en Brasil". Documentos y Aportes en Administración Pública y Gestión Estatal, nº 9, pp. 31-58.

JARD DA SILVA, Sidney. (2007a), Reforma da Previdência em perspectiva comparada: executivo, legislativo e sindicatos na Argentina e no Brasil. São Paulo, Humanitas/Fapesp.

. (2007b), “The Executive and Legislative Branches and Trade Unions in the Argentine Social Security Reform". Tradução: André Villalobos. DADOS [online], vol. 3, Selected Edition. Disponível <http://socialsciences.scielo.org/scielo.php?script=sci_ arttext\&pid=S0011-52582007000100007\&lng=en\&nrm=iso>. ISSN 0011-5258.

KAY, Stephen J.; SINHA, Tapen. (2008), Lessons from Pension Reform in the Americas. Oxford: Oxford University Press.

LADOSKY, Mario Henrique Guedes; JÁCOME RODRIGUES, Iram. (2018), “A CUT e o sindicalismo brasileiro nos anos recentes: limites e possibilidades". Tempo Social, vol. 30, $\mathrm{n}^{\circ} 1$, pp. 53-76.

LEMOS, L. B. (2006), “El sistema de comisiones en el Senado brasileño: jerarquía y concentración de poderes en la década de 1990". América Latina Hoy, Salamanca, nº 43, pp. 155-182.

LEWIS, Colin M.; LLOYD-SHERLOCK, Peter. (2002), "Social insurance regimes: crises and 'reform' in Argentine and Brazil, since c. 1900". Working Papers in Economic History, $\mathrm{n}^{\circ}$ 68/02, London School of Economics.

MADRID, Raúl L. (2003), Retiring the State: the politics of pension privatization in Latin America and Beyond. Stanford: Stanford University Press.

MALLOY, James M. (1986), A política da previdência social no Brasil. Tradução de Maria José Lindgren Alves. Rio de Janeiro: Graal.

MAQUIAVEL, Nicolau. (1983 [1515]), O Príncipe. Coleção os Pensadores. São Paulo: Abril Cultural.

MARTINS RODRIGUES, Leôncio; SADEK, Maria T. A. (2010), El Brasil de Lula: diputados y magistrados. Rio de Janeiro: Centro Edelstein de Pesquisas Sociais. Disponível em http:// static.scielo.org/scielobooks/ctdh3/pdf/rodrigues-9788579820359.pdf.

MARTINS RODRIGUES, Leôncio. (2009), Mudanças na classe política brasileira. Rio de Janeiro: Centro Edelstein de Pesquisas Sociais. Disponível em http://static.scielo.org/ scielobooks/h6kh6/pdf/rodrigues-9788579820113.pdf. 
Sidney Jard da Silva

MARX, Karl. (2011 [1852]), O 18 de Brumário de Luís Bonaparte. Tradução e notas Nélio Schneider. São Paulo: Boitempo.

MELO, Carlos R.; ANASTASIA, Fátima. (2006), "Social Security Reform in two stages". DADOS [online]. $\mathrm{n}^{\circ}$ 2. Disponível em http:/ / socialsciences.scielo.org/scielo.php?pid=S0011$-52582006000200005 \&$ script=sci_arttext.

. (2005), "A Reforma da Previdência em dois tempos". Dados - Revista de Ciências Sociais, vol. 48, n 2, pp. 301-332.

MELO, Marcus A. (2004), “Escolha institucional e a difusão dos paradigmas de política: o Brasil e a segunda onda de reformas previdenciárias". Dados - Revista de Ciências Sociais, vol. 47, $\mathrm{n}^{\circ} 1$, pp. 169-205.

. (2002), Reformas constitucionais no Brasil: instituições politicas e processo decisório. Rio de Janeiro: Editora Revan.

MARQUES, Rosa M.; BATICH, Mariana; MENDES, Áquila. (2003), “Previdência social brasileira: um balanço da reforma". São Paulo em Perspectiva, vol. 17, n 1, pp. 111-121.

MESA-LAGO, Carmelo. (1977), Modelos de seguridad social en América Latina: estudio comparativo. Tradução de Mario R. dos Santos. Buenos Aires: Ediciones Siap-Planteos.

MURILLO, Maria V. (2001), Labor unions, partisan coalitions, and market reforms in Latin America. Cambridge: Cambridge University Press.

(2000), "Del populismo al neoliberalismo: sindicatos y reformas de mercado en América Latina”. Desarrollo Económico, vol. 40, nº 158, pp. 179-212.

NAKAHODO, Sidney N.; SAVOIA, José R. (2008), “A Reforma da Previdência no Brasil: estudo comparativo dos governos Fernando Henrique Cardoso e Lula". Revista Brasileira de Ciências Sociais, vol. 23, nº 66. Disponível em http://www.scielo.br/scielo. php?script=sci_arttext\&pid=S0102-69092008000100003\&lng=en\&nrm=iso.

ORTIZ, Isabel et al. (2019), "La reversión de la privatización de las pensiones: Reconstruyendo los sistemas públicos de pensiones en los países de Europa Oriental y América Latina (2000-2018)". Documento de Trabajo, nº 63. Genebra: Departamento de Proteção Social, Organização Internacional do Trabalho. Disponível em https:/ / www.social-protection. org/gimi/RessourcePDF.action?id=55496

PACHECO, Luciana B.; MENDES, Paula R. (2017), Questões sobre processo legislativo e regimento interno. Brasília: Edições Câmara.

PALERMO, Vicente. (2016), "Brazilian political institutions: an inconclusive debate". Brazilian Political Science Review. vol. 10, n 2. Disponível em dx.doi.org/10.1590/198138212016000200003.

(2000), "Como se governa o Brasil? O debate sobre instituições políticas e gestão de governo”. DADOS [online], vol. 43, n³, pp. 521-557. Disponível em dx.doi. org/10.1590/S0011-52582000000300004.

PEREIRA, Carlos; MUELLER, Bernardo. (2000), “Uma teoria da preponderância do Poder Executivo: o sistema de comissões no Legislativo brasileiro". Revista Brasileira de Ciências Sociais, vol. $15, \mathrm{n}^{\circ} 43$, pp. $46-67$. 
QUEIROZ, Antônio A. (2004), "PEC Paralela e os servidores públicos". Agência Diap, 16 de janeiro. Disponível em http://www.sintunesp.org.br/refprev/federal/PEC\%20Paralela\%20e $\% 20$ serv $\% 20$ p $\%$ C3\%BAblicos.htm

RAMALHO, José R. (2011), “Trabalho e trabalhadores: organização e lutas sociais". In: A. Botelho; L. M. Schwarcz (orgs.), Agenda brasileira: temas de uma sociedade em mudança. São Paulo: Companhia das Letras.

RICCI, Paolo. (2003), “O conteúdo da produção legislativa brasileira: leis nacionais ou políticas paroquiais?" DADOS, vol. 46, n 4, pp. 699-734. Disponível em dx.doi.org/10.1590/ S0011-52582003000400003.

SANTANA, Marco A.; BRAGA, Ruy. (2009), “O pêndulo oscilante: sociologia do trabalho e movimento sindical no Brasil". Caderno CRH, vol. 22, n56, pp. 297-309.

SANTOS, Fabiano; ALMEIDA, Alcir. (2011), Fundamentos informacionais do presidencialismo de coalizão. Curitiba: Appris.

SILVEIRA, Rafael; SILVA, Rafael. (2014), “Beyond Brazilian coalition presidentialism: the appropriation of the legislative agenda". Brazilian Political Science Review, vol. 8, n 3, pp. 95-133. Disponível em https:/ /dx.doi.org/10.1590/1981-38212014000100022.

SINHA, Tapen. (2000), Pension Reform in Latin America and its Lessons for International Policymakers. Boston: Kluwer Academic Pubishers.

TSEBELIS, George. (1998), Jogos ocultos: escolha racional no campo da Política Comparada. São Paulo: Editora da Universidade de São Paulo.

. (1997), “Processo decisório em sistemas políticos: veto players no presidencialismo, parlamentarismo, multicameralismo e pluralismo". Revista Brasileira de Ciências Sociais, vol. 12, n 34, pp. 89-117.

WATERMAN, Peter. (2002), “O internacionalismo sindical na era de Seatle”. Revista Crítica de Ciências Sociais, ${ }^{\circ}$ 62, pp. 33-68. 


\section{RESUMO}

Sindicalismo, Processo Decisório e Reforma da Previdência no Governo Lula

O presente artigo analisa o trâmite legislativo da reforma da Previdência no governo Lula. O foco do artigo está concentrado no papel desempenhado pela bancada sindical (deputados e senadores) no acordo político para a aprovação da PEC Paralela da Previdência. A restrição da análise ao trâmite parlamentar da matéria não é fortuita, trata-se de um recorte teórico-metodológico direcionado para o locus principal do processo decisório das reformas previdenciárias em regimes democráticos: a arena legislativa. Em situações político-institucionais em que um governo considerado aliado apresenta uma proposição legislativa que contraria os interesses de setores importantes da base sindical, os parlamentares sindicalistas votam a favor ou contra o projeto encaminhado pelo Executivo? Os achados da pesquisa confirmam a hipótese da predominância da orientação partidária sobre o comportamento parlamentar da bancada sindical. No entanto, os resultados encontrados também demonstram que não se trata de mera subordinação política, mas, sim, de um complexo processo de negociação envolvendo atores institucionais, partidários e sindicais.

Palavras-chave: governo Lula; sindicalismo; reforma da Previdência; processo decisório; relações Executivo-Legislativo

\section{ABSTRACT \\ Unionism, Decision-Making Process, and Pension Reform in Lula's Government}

This article analyzes the legislative process of pension reform in Lula's government. The focus of the work is the role played by the union caucus (deputies and senators) in the political agreement for the approval of the PEC Paralela da Previdência. The analysis's restriction to the parliamentary procedure of the matter is not accidental, it is a theoretical-methodological approach directed to the main locus of the decision-making process of social security reforms in democratic regimes: the legislative arena. In political-institutional situations in which a government considered an ally presents a legislative proposal that contradicts the interests of important sectors of the union base, do union parliamentarians vote in favor or against the project submitted by the Executive? The research findings confirm the hypothesis of the predominance of party guidance over the parliamentary behavior of the union bloc. However, the results also demonstrate that it is not a matter of mere political subordination, but a complex negotiation process involving institutional, party and union agents.

Keywords: Lula government; unionism; social security reform; decision-making process; Executive-Legislative relations 


\section{RÉSUMÉ}

Syndicalisme, processus de prise de décision et Reforme de la Sécurité Sociale au sein du gouvernement Lula

Cet article analyse le processus législatif de la Reforma da Previdência au sein du gouvernement Lula. On se concentre sur le rôle joué par le banc syndical (députés et sénateurs) dans l'accord politique pour l'approbation de la PEC Paralela da Previdência. La restriction de l'analyse à la procédure parlementaire de la question n'est pas accidentelle, il s'agit d'une approche théorico-méthodologique dirigée vers le locus principal du processus décisionnel des réformes de la sécurité sociale dans les régimes démocratiques: l'arène législative. Dans les situations politico-institutionnelles où un gouvernement considéré comme un allié présente une proposition législative qui contredit les intérêts de secteurs importants de la base syndicale, les parlementaires syndicaux votent favorablement ou contrairement au projet soumis par l'exécutif? Les résultats de la recherche confirment l'hypothèse de la prédominance de l'orientation des partis sur le comportement parlementaire du banc syndical. Cependant, les résultats trouvés démontrent également qu'il ne s'agit pas d'une simple subordination politique, mais d'un processus de négociation complexe impliquant des acteurs institutionnels, partisans et syndicaux.

Mots-clés: gouvernement Lula; syndicalisme; réforme de la Sécurité Sociale; processus de prise de décision; rapports Exécutif-Législatif.

\section{RESUMEN}

Sindicalismo, Proceso de Toma de Decisiones y Reforma Previsional en el Gobierno de Lula

El presente artículo analiza el trámite legislativo de la reforma previsional en el gobierno de Lula. El foco del trabajo se concentra en el papel desempeñado por la bancada sindical (diputados y senadores) en el acuerdo político para la aprobación de la PEC Paralela da Previdência. La delimitación del análisis para el trámite parlamentario de este asunto no es fortuita, pues se trata de un recorte teórico metodológico direccionado para el locus principal del proceso de toma de decisiones de las reformas previsionales en regímenes democráticos: la arena legislativa. ¿En situaciones político-institucionales en las que un gobierno considerado aliado presenta una propuesta legislativa que contraría los intereses de sectores importantes de la base sindical, los parlamentarios sindicalistas votan a favor o en contra del proyecto enviado por el Ejecutivo? Los hallazgos de la investigación confirman la hipótesis de la predominancia de la orientación partidaria sobre el comportamiento parlamentario de la bancada sindical. Sin embargo, los resultados 
Sidney Jard da Silva

encontrados también demuestran que no se trata de una mera subordinación política, pero si, de un complejo proceso de negociación involucrando actores institucionales, partidarios y sindicales.

Palabras clave: gobierno Lula; sindicalismo; reforma Previsional; proceso de toma de decisiones; relaciones Ejecutivo-Legislativo. 